\title{
Rain Drop Measurement Techniques: A Review
}

\author{
Gopinath Kathiravelu ${ }^{\dagger}$, Terry Lucke ${ }^{*}{ }^{\dagger}$ and Peter Nichols ${ }^{\dagger}$ \\ Received: 17 November 2015; Accepted: 4 January 2016; Published: 21 January 2016 \\ Academic Editor: Brigitte Helmreich \\ Stormwater Research Group, School of Science and Engineering, University of the Sunshine Coast, \\ Sippy Downs, Queensland 4556, Australia; gkathira@usc.edu.au (G.K.); pnichols@usc.edu.au (P.N.) \\ * Correspondence: tlucke@usc.edu.au; Tel.: +61-754-565-185 \\ + These authors contributed equally to this work.
}

\begin{abstract}
For over a century there have been many studies that describe the use of rain drop measurement techniques. Initial manual measurement methods evolved due to improved technology to include photographic and, more recently, automated disdrometer and laser measurement techniques. Despite these numerous studies, there have been few comparative reviews of the range of methodologies, and their relative performance. This review explores the raindrop measurement techniques available, and summarizes and classifies the techniques according to the method or principle involved. The requirements of a robust raindrop measurement technique are suggested, and these are reviewed against existing rain drop measurement techniques to provide a comparative guide to the use of the range of techniques available for any research study. This review revealed that while advances in technology have allowed many of the deficiencies of early techniques to be eliminated, challenges remain in relation to the precision of the measurement of the size, shape, and velocity of rain drops.
\end{abstract}

Keywords: raindrop measurement techniques; impact and optical disdrometers; laser precipitation monitor; pluviometer

\section{Introduction}

An appreciation of rain drop characteristics such as size, shape, velocity, kinetic energy, and drop size distribution is crucial for many scientific, commercial and industrial applications. Some examples of these include remote sensing, meteorology (weather prediction), telecommunications (signal distortion), and agriculture and horticulture (crop yield) radar meteorology, atmospheric physics, cloud photodetection, and measurement of tropospheric precipitation microstructure [1-3].

The characteristics of rain drops are also important for stormwater management purposes, particularly in relation to understanding how pollution wash off processes affect stormwater quality. For example, larger rain drops that possess more kinetic energy are known to result in higher pollution concentrations being washed off impervious surfaces and into downstream aquatic environments [4].

The objective of this review is to provide a summary of the development of rainfall measurements techniques, and to review and compare the different rain drop measurement techniques used in previous research studies. The scope of this review has been limited to include only those measurement techniques with the ability to measure rain drop size, shape, distribution, velocity, kinetic energy, and intensity. Different raindrop measurement techniques have been characterised according to the method used, and the relative merits of each method are discussed. In order to compare the merits of each technique, rain drop measurement methods included in this review have been broadly categorised into manual and automated techniques.

Manual rain drop measurement techniques include the stain method (measurement of stains on dyed absorbent paper), flour pellet method (measurement of rain drops that fall into finely sieved 
flour and produce dough pellets), and oil immersion method (measurement of rain drops in a vessel containing oil). Despite these manual methods being simple, they are time consuming, have limited measurement accuracy, and do not give real time data records. Also, these manual techniques cannot provide terminal velocity data, which is required to estimate the kinetic energy of rainfall [5]. Manual techniques are reviewed in the first part of this article.

Recent advances in technology and electronics have enabled an exploration of automated rain drop measurement techniques. These are reviewed in the second part of this article and include techniques such as the using devices to measure the displacement and mechanical energy caused by raindrops hitting a surface, optical imaging to measure the velocity, diameter, and shape of the raindrops using camera technology, acoustic techniques which measure the noise produced by rain drops hitting a diaphragm and optical scattering, whereby rain drop size, shape, velocity, and diameter are measured passing through a light or laser beam.

In the final section of this article, the essential characteristics required for an accurate rain drop measurement technique are suggested and explained. A summary and conclusions of the review are presented.

\section{Manual Rain Drop Measurement Techniques}

Early studies (ca. 1900-1960) attempted to describe rain drop size and velocity using manual measurement techniques such as chemically treated paper, and sugar or soot coated nylon screen [6-8]. These very early, functional techniques were found to provide inaccurate results, and have been superseded due to technological advancement over the last century.

\subsection{Stain Method}

The stain method was one of the earliest accepted techniques to be developed and it is still in use today. First described by Lowe [9], this method involves the use of chemically treated paper to measure the size of raindrops. For a short period of time rain drops are allowed to land on a sheet of absorbent paper covered with a water-soluble dye. A variety of absorbent papers have previously been used including filter paper, blotting paper, blueprint paper, paper towelling, photographic paper, and adding machine tape. Upon impact, the embedded dye reacts with the rain drops and this leaves permanent marks on the paper. The marks are then carefully measured and counted to provide information about the rain drops. One of the limitations of this method is that during prolonged sampling, the rain drop stains can overlap, which can make it difficult to accurately measure and count individual drops.

Several iterations of this method over time improved measurement accuracy, and increased size range measurement capacity including developments of the method described by Marshall and Palmer [10], and Marshall et al. [11] who used dyed filter paper. Two filter papers were used simultaneously to increase the accuracy of rain drop measurement. Ink blotters dusted with potassium manganese used by Anderson [12] and known water densities used by Abudi et al. [13], incorporated weights of raindrops to infer size. Several studies [14-22] used Whatman's No. 1 filter paper, which was identified as yielding the most accurate results.

Bowen and Davidson [23] trialled an improvement to the stain method by using a semi-automated technique which produced a continuous record of the drop size distribution. The improved method involved deflection of rain drops onto moving absorbent paper embedded with dye. The diameters of the stains were categorised into five different size classes, from which drop size distributions were calculated. A similar recording instrument in which paper tape was used to record rain drops was developed in conjunction with an equation which described drop size in relation to stain size and time lag between sampling and analysis [24-27]. Calculations resulted in a calibration chart which translated the stained area caused by rain drops into raindrop diameter $[14,15]$. Limitations of this methodology included the uncertainty of allowing for terminal velocity of the rain drop prior to 
measurement $[15,28,29]$, and maintenance of paper temperatures, which were both found to influence stain sizes [30].

\subsection{Flour Pellet Method}

First developed in 1904 by Bentley [31], the flour pellet method (Figure 1) was used to study drop size distributions of rain events in Washington D.C., USA. A number of studies have since used slightly different versions of the flour pellet method to successfully analyse rainfall (Table 1).

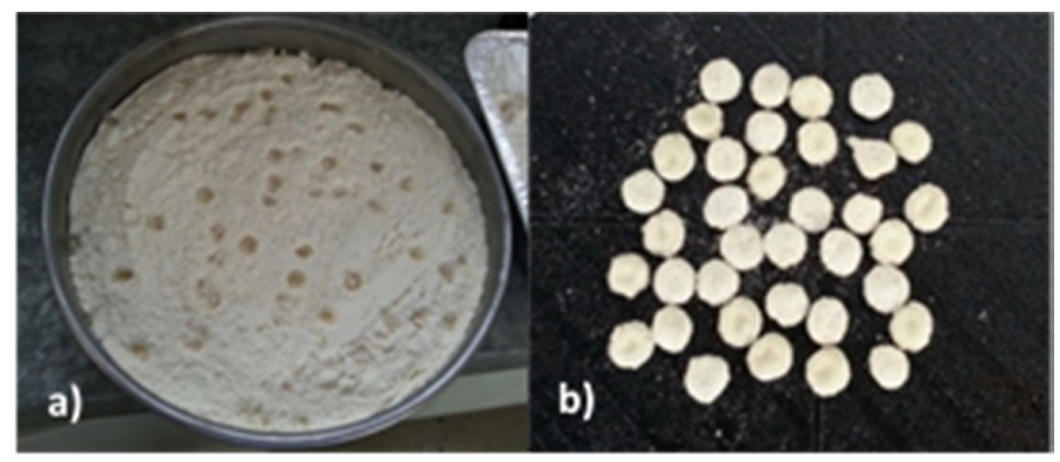

Figure 1. (a) Raindrop flour pellet samples collected in a pan filled with $2 \mathrm{~cm}$ depth of plain flour; (b) Flour pellets after oven drying.

Compaction of the flour over time was found to affect measured pellet size, and large sample numbers are usually required to account for the high variability in the number of rain drops observed during testing [32]. Test area should be restricted to the centre of the chosen collection tray to avoid splash effects. The test duration should also be brief (1-2 s) to avoid duplicate drop counts [4,33-39].

The chief technological advance to the flour pellet method was developed by Arnaez et al. [40], who used digital analysis of photographs to determine drop sizes. The main fields that still currently use the flour pellet method include soil erosion, and stormwater quality research studies $[4,35,36,38-46]$.

Table 1. The research studies used the flour pellet method.

\begin{tabular}{|c|c|c|}
\hline Research Study and Location & Purpose of Use & Method used \\
\hline Laws \& Parsons (1943) [47] & $\begin{array}{l}\text { To measure drop sizes from } \\
\text { natural storms }\end{array}$ & $\begin{array}{l}\text { After sampling with raindrops, the formed } \\
\text { pellets were dried in an oven. Pellets were } \\
\text { sized with sieves and weighed. The size } \\
\text { was calibrated by weighing dried pellets } \\
\text { produced by drops of a known size. }\end{array}$ \\
\hline Hudson (1963) [33] & $\begin{array}{l}\text { To measure drop sizes from } \\
\text { natural storms }\end{array}$ & $\begin{array}{l}\text { A tray }\left(0.05 \mathrm{~m}^{2}\right) \text { of flour was exposed to } \\
\text { simulated rainfall for a period of } 1 \mathrm{~s} \text {. } \\
\text { The flour was then dried for } 24 \mathrm{~h} \text { at ambient } \\
\text { temperature }\left(28-30^{\circ} \mathrm{C}\right) \text { and the pellets } \\
\text { formed were passed through a series of sieves } \\
(4.75,3.35,2.36,1.18 \text { and } 0.85 \mathrm{~mm}) \text {. } \\
\text { The pellets were then dried for } 24 \mathrm{~h} \text { at } 105^{\circ} \mathrm{C} \text {, } \\
\text { weighed and measured. }\end{array}$ \\
\hline Kohl (1974) [32] & $\begin{array}{l}\text { To verify the nozzle } \\
\text { produced drop sizes in the } \\
\text { rainfall simulation studies }\end{array}$ & $\begin{array}{l}\text { Circular pans } 21 \mathrm{~cm} \text { in diameter and } 2 \mathrm{~cm} \\
\text { deep were filled with flour and made level } \\
\text { with a straight edge. After exposure to rain } \\
\text { drops, the flour was dried }\left(24 \mathrm{~h} \text { at } 38{ }^{\circ} \mathrm{C}\right) \text {. } \\
\text { An } 18.3 \mathrm{~cm} \text { diameter sample was taken from } \\
\text { the centre of the pan to avoid splash effects. } \\
\text { The pellets were sieved (U.S. series } 5 \text { to } \\
50 \text { mesh) and weighed. }\end{array}$ \\
\hline
\end{tabular}


Table 1. Cont.

\begin{tabular}{|c|c|c|}
\hline Research Study and Location & Purpose of Use & Method used \\
\hline Carter et al. (1974) [48] & $\begin{array}{l}\text { To study drop size } \\
\text { distribution of } \\
\text { natural rainfall }\end{array}$ & $\begin{array}{l}\text { A circular pan ( } 31 \mathrm{~cm} \text { diameter) of flour } \\
(1.6 \mathrm{~cm} \text { deep), was exposed in a rain for a } \\
\text { short period of time. The pellets formed were } \\
\text { first air- and later oven-dried and weighed. } \\
\text { Raindrop diameter was estimated from the } \\
\text { weight of the pellets. }\end{array}$ \\
\hline Navas et al. (1990) [49] & $\begin{array}{l}\text { To verify the nozzle } \\
\text { produced drop sizes in the } \\
\text { rainfall simulation studies }\end{array}$ & $\begin{array}{l}\text { A } 25.4 \mathrm{~cm} \text { diameter plate containing an } \\
\text { uncompacted, layer of flour }(2.54 \mathrm{~cm} \text { thick }) \text { is } \\
\text { exposed to rainfall for } 1-4 \mathrm{~s} \text {. The small flour } \\
\text { balls are dried for } 24 \mathrm{~h} \text { at } 105^{\circ} \mathrm{C} \text {, and sieved } \\
(5000,3000,1000,630,500 \text { and } 250 \mu \mathrm{m}) \text { the } \\
\text { fractions are weighed. Calibration of drops } \\
\text { is required. }\end{array}$ \\
\hline $\begin{array}{l}\text { Ogunye and } \\
\text { Boussabaine (2002) [35] }\end{array}$ & $\begin{array}{l}\text { To verify the simulated drop } \\
\text { sizes in the rainfall } \\
\text { simulation studies }\end{array}$ & $\begin{array}{l}\text { Exposure time is restricted to } 1 \mathrm{~s} \text { to minimise } \\
\text { coalescence of the pellets in the flour. A large } \\
\text { sample size is required to minimise the } \\
\text { variability in counts of the rare large drops. }\end{array}$ \\
\hline Arnaez et al. (2007) [40] & $\begin{array}{l}\text { To verify the nozzle } \\
\text { produced drop sizes in the } \\
\text { rainfall simulation studies. }\end{array}$ & $\begin{array}{l}\text { Rain drops formed small pellets in the flour } \\
\text { that were photographed and analysed by } \\
\text { computer. }\end{array}$ \\
\hline $\begin{array}{l}\text { Herngren (2005) [4]; } \\
\text { Egodawatta (2007) [44]; } \\
\text { Miguntanna (2009) [38] }\end{array}$ & $\begin{array}{l}\text { To verify the nozzle } \\
\text { produced drop sizes in the } \\
\text { rainfall simulation studies. }\end{array}$ & $\begin{array}{l}\text { A tray (diameter } 240 \mathrm{~mm} \text { ) of uncompacted } \\
\text { flour was exposed to simulated rainfall for a } \\
\text { period of } 2 \mathrm{~s} \text {. Flour was dried for } 12 \mathrm{~h} \text { at } \\
105^{\circ} \mathrm{C} \text {, and the pellets sieved }(4.75 \mathrm{~mm} \text {; } \\
3.35 \mathrm{~mm} ; 2.36 \mathrm{~mm} ; 1.18 \mathrm{~mm} ; 0.6 \mathrm{~mm} \text {; } \\
\text { and } 0.5 \mathrm{~mm}) .\end{array}$ \\
\hline Pérez-Latorre et al. (2010) [39] & $\begin{array}{l}\text { To verify the nozzle } \\
\text { produced drop sizes in the } \\
\text { rainfall simulation studies. }\end{array}$ & $\begin{array}{l}\text { A flour layer }(1 \mathrm{~cm} \text { depth) was placed over a } \\
\text { surface of } 50 \mathrm{~cm} \times 50 \mathrm{~cm} \text { and compacted } \\
\text { using a ruler. The flour surface was covered } \\
\text { to protect it from rainfall except when the } \\
\text { cover was removed for } 2 \mathrm{~s} \text { during the } \\
\text { simulation to collect drop samples. } \\
\text { The diameter of pellets was measured using } \\
\text { a calibre }( \pm 0.1 \mathrm{~mm}) .\end{array}$ \\
\hline Asante (2011) [45] & $\begin{array}{l}\text { To verify the nozzle } \\
\text { produced drop sizes in the } \\
\text { rainfall simulation studies. }\end{array}$ & $\begin{array}{l}\text { A thin layer of cassava flour, and wheat flour } \\
\text { were spread on separate trays and passed } \\
\text { through a rain shower. The flour was dried } \\
\text { and the pellets separated according to their } \\
\text { size ranges using a nest of sieves. The size } \\
\text { of raindrops was calculated from the size } \\
\text { of pellets. }\end{array}$ \\
\hline Parsakhoo et al. (2012) [46] & $\begin{array}{l}\text { To verify the nozzle } \\
\text { produced drop sizes in the } \\
\text { rainfall simulation studies. }\end{array}$ & $\begin{array}{l}\text { The drop impact on flour was estimated } \\
\text { using a ruler. }\end{array}$ \\
\hline
\end{tabular}

\subsection{Oil Immersion Method}

An early manual rain drop measurement method first developed by Fuchs and Petrjanoff [50], the oil immersion method involves the collection of drops on a glass trough containing a fresh mixture of lightly viscose liquids, such as Vaseline ${ }^{\circledR}$ and light mineral oil which prevents evaporation and condensation [51-58]. Using a camera and microscope, this technique does not require calibration or special equipment [55].

The low viscosity and hydrophobic nature of the oil causes rain drops to form discreet spherical shapes, allowing drop counting and measurement by microscope [59] or via photograph [57,58,60]. Generally any low viscosity oil can be used [61], and several alternative liquids have been utilised in a range of studies, including Apiezon oil A, Shell 33, vacuum pump oil, paraffin oil and hydraulic 
fluid mixture, hydro carbon solvent, silicone oil, anisole mineral oil mixture, cold hexane, and grease $\left(-20^{\circ} \mathrm{C}\right)$ [57-60,62-67]. Courshee and Byass [59] found that the use of two oils of different densities improved drop shape measurement. Using a microscope or a photograph, they found it easier to identify the drops trapped at the liquid interface (two liquids) rather than one.

\subsection{Photographic Method}

The photographic method has been used extensively to measure rain drop size and velocity, and undergone many iterative improvements since its development by Mache in 1904 [68] (Table 2). Initially, Laws [69] measured drop sizes using a $9 \mathrm{~cm} \times 12 \mathrm{~cm}$ still camera mounted behind a chopper-disc driven by a small synchronous motor (Figure 2 ).

Light infiltration problems have restricted some use of the photographic method to night time sampling $[7,70,71]$. Use of the Illinois camera resulted in drop count errors due to superimposition of multiple drops [70]. Digital pixilation also limited the accuracy of several photographic techniques [72]. In addition, photographic techniques are subject to environmental influences such as wind which may cause drop drift and measurement errors [73]. The time consuming nature of some experimental photographic techniques were found to limit their practical use [74].

Table 2. Range of photographic methods used in rainfall measurements studies.

\begin{tabular}{|c|c|}
\hline Research Study & Methodology and other Comments \\
\hline Abudi et al. (2012) [13] & $\begin{array}{l}\text { A Motion-Scope }{ }^{\circledR} \text { PCI-8oosc camera (Redlake Imaging Corp., San Diego, } \\
\text { CA, USA) was used in conjunction with special software capture } \\
\text { falling drops. Calibration of images resulted in drop velocity and } \\
\text { size measurement. }\end{array}$ \\
\hline De Jong (2010) [73] & $\begin{array}{l}\text { A Canon Powershot }{ }^{\circledR} \text { camera (Canon Inc., Tokyo, Japan) was with a } \\
\text { Stopshot }{ }^{\circledR} \text { module (Cognisys Inc., Traverse City, MI, USA) which } \\
\text { triggered two successive flashes. The process was activated by an } \\
\text { infrared sensor passed by a raindrop drop. Drop images were captured } \\
\text { twice allowing velocity measurement (Figure 3). }\end{array}$ \\
\hline Salvador et al. (2009) [72] & $\begin{array}{l}\text { Low shutter speeds result in drops appearing as cylinders in a } \\
\text { photograph. Drop diameter and velocity were calculated based on the } \\
\text { selected shutter speed. }\end{array}$ \\
\hline Sudheera and Panda (2000) [75] & $\begin{array}{l}\text { High resolution photographs were digitised using a scanner. A digital } \\
\text { single lens reflex (SLR) camera produced digital images converted by a } \\
\text { CCD (charge couple device) camera connected to a MVP / AT computer } \\
\text { system. Pixel aggregation was used to partition images to allow drop } \\
\text { size and count measurement. }\end{array}$ \\
\hline $\begin{array}{l}\text { Cruvinel et al., \& Cruvinel et al. } \\
(1996,1999)[58,61]\end{array}$ & $\begin{array}{l}\text { A Sony }{ }^{\circledR} \text { TR50BR handycam video (Sony, Minato, Tokyo) and a } \\
\text { MATROX }{ }^{\circledR} \text { PIP-640B (Matrox, QC, Canada) were used in conjunction } \\
\text { with oil immersion to calculate drop sizes. }\end{array}$ \\
\hline $\begin{array}{l}\text { Eigel and Moore \& Kincaid et al. } \\
(1983,1996)[57,76]\end{array}$ & $\begin{array}{l}\text { Drops were photographed using a } 35 \mathrm{~mm} \text { Fujichrome }{ }^{\circledR} 100 \text { (Fujifilm, } \\
\text { Tokyo, Japan) and illuminated with a circular fluorescent light. Slides } \\
\text { projected on a screen resulting in a } 30: 1 \text { magnification, supporting small } \\
\text { drop measurement ( } 0.1 \mathrm{~mm} \text { diameter). }\end{array}$ \\
\hline $\begin{array}{l}\text { Mueller (1966) [77], } \\
\text { Jones (1959) [78], } \\
\text { Jones and Dean (1953) [79], } \\
\text { Jones (1956) [80] }\end{array}$ & $\begin{array}{l}\text { An Illinois camera was used to capture raindrops in an area of } 1 \mathrm{~m}^{3} \text { of } \\
\text { air every } 10 \mathrm{~s} \text {. This involved two synchronised cameras at perpendicular } \\
\text { angles. The three-dimensional image of the shape of the raindrops was } \\
\text { then calculated. The accuracy of this method was limited to }>0.5 \mathrm{~mm} \text { in } \\
\text { drop size [81]. }\end{array}$ \\
\hline Laws (1941) [69] & $\begin{array}{l}\text { A still camera was used mounted behind a chopper-disk driven by a } \\
\text { small synchronous motor (Figure 2). A collimating lens resulted in } \\
\text { accurate drop size measurement. Dark field illumination and the } \\
\text { chopper-disk made it possible to obtain multiple images of a drop on a } \\
\text { single film. }\end{array}$ \\
\hline
\end{tabular}




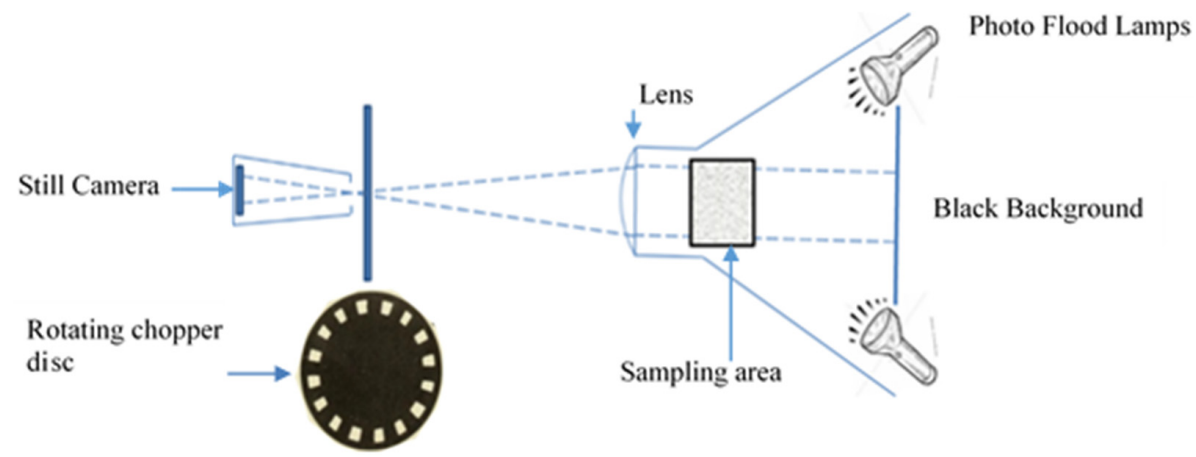

Figure 2. Schematic still camera setup developed to measure the velocity of falling drops [68].

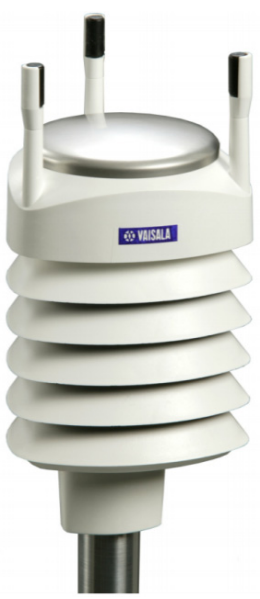

Figure 3. Vaisala Rain Cap disdrometer (Vaisala, Vantaa, Finland)[82].

\section{Automated Rain Drop Measurement Techniques}

\subsection{Impact Disdrometers}

The kinetic energy of rain drops is critical to soil erosion and stormwater pollutant wash off studies because it is indicative of the potential of drops to displace particles normally bound to a surface, causing to soil particles to enter surface water flows. The combination of drop size distribution and drop velocity can provide an estimation of kinetic energy, however there have been several previous attempts to take measurements directly [83-85]. This has been done using either acoustic or displacement methods.

\subsubsection{Acoustic Disdrometers}

Acoustic disdrometers involve the generation and recording of an electric signal via a piezoelectric sensor when drops fall on a specialized diaphragm. Based on the relationship between kinetic energy and drop size calculations $[53,69]$, this electrical signal is converted to kinetic energy via the measured acoustic energy [73,83-95].

Modifications to the sensors used in acoustic disdrometers by Nystuen et al. [96] enabled use in marine environments, however difficulties remained during high rainfall intensity measurement. Jayawardena and Rezaur [83] also successfully modified the acoustic disdrometers, and improved drop size distribution, rain intensity and kinetic energy measurement accuracy. Other commercial devices have been successfully developed by Salmi and Ikonen [97], Salmi and Elomaa [84], Winder and Paulson [86], Bagree [98] and Vaisala [82] (Figure 3). 
Limitations to accuracy in drop size estimation arise using acoustic disdrometers due to the difficulty in obtaining a uniform acoustic response over the entire diaphragm. Difficulties in the accurate measurement of smaller drop sizes also remain because of insensitive diaphragms, and splash effects. In addition, higher intensity storms are not able to be measured due to background noise which decreases measurement accuracy.

\subsubsection{Displacement Disdrometers}

Energy generated by drops falling on the top surface of a displacement disdrometer is translated via magnetic induction, and converted via electrical pulse to estimate the size of a rain drop (Figure 4).

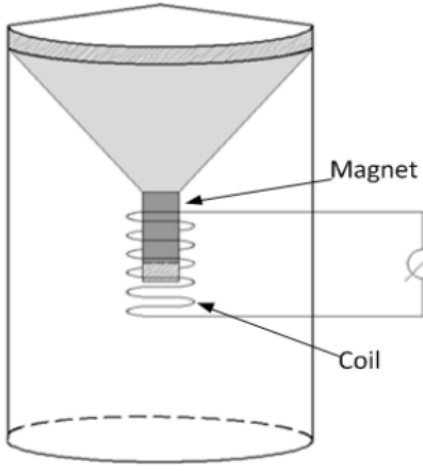

(a)Normal Condition

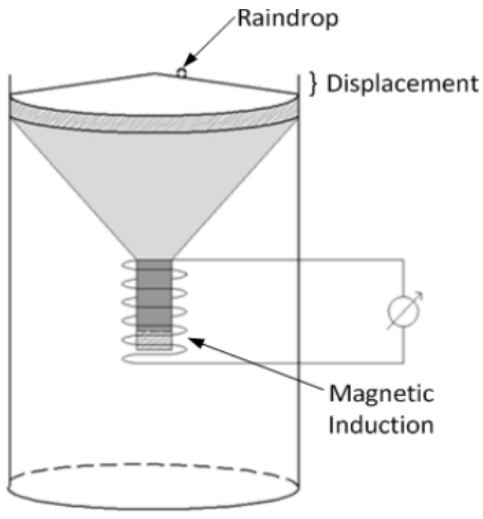

(b) When drop impinges on the surface

Figure 4. Schematic of the principle of operation of displacement disdrometers [98].

In addition to magnetic induction, several mechanisms have previously been trialled to accurately measure drop size including elastic springs [98], bonded strain gauges [99], and pressure transducers [84,100-103]. Arguably the most widely used displacement disdrometer is the Joss-Waldvogel Disdrometer [85] (Figure 5) which has been commercially available for past 45 years. This unit has undergone several iterations to improve the composition of the cone which is the principle measurement component. Successful modifications have included the addition of a digital converter [104-106] (Table 3). Although this disdrometer may have provided advantages such as measurement over a wide range of drop sizes, and the ability to continuously sample over longer durations, limitations remain including accurate drop counting, and accurate measurement of velocity, kinetic energy, intensity, and drop shape.

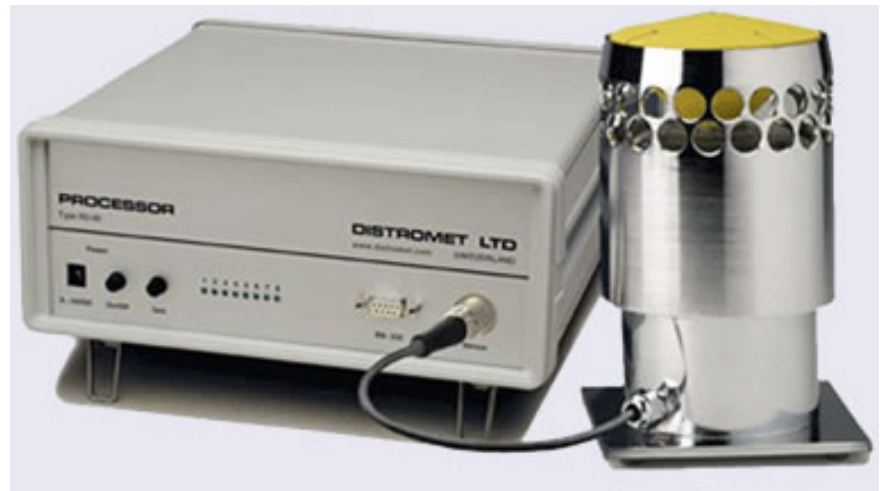

Figure 5. Joss-Waldvogel impact disdrometer (Distromet Ltd., Basel, Switzerland) [106]. 
Table 3. Capability summary of a range of optical disdrometers.

\begin{tabular}{|c|c|c|c|c|c|c|}
\hline Device Name & Study & $\begin{array}{l}\text { Rainfall } \\
\text { Intensity }\end{array}$ & Drop Size & Fall Speed & $\begin{array}{l}\text { Kinetic } \\
\text { Energy }\end{array}$ & $\begin{array}{l}\text { Sampling Area } \\
\text { (Thickness of } \\
\text { Light Beam) }\end{array}$ \\
\hline $\begin{array}{c}\text { Thies Clima }{ }^{\circledR} \text { Laser } \\
\text { Precipitation } \\
\text { Monitor (LPM) } \\
\text { (Adolf Thies } \\
\text { GmbH \& Co. KG, } \\
\text { Göttingen, } \\
\text { Germany) }\end{array}$ & $\begin{array}{c}\text { Bloemink \& } \\
\text { Lanzinger (2005) } \\
\text { [107]; Clima (2007) } \\
\text { [108]; Upton \&Brawn } \\
\text { (2008) [109]; } \\
\text { Anderson (2009) [110]; } \\
\text { de Moraes Frasson } \\
\text { (2011) [111] }\end{array}$ & $<250 \mathrm{~mm} / \mathrm{h}$ & $<8.5 \mathrm{~mm}$ & $<11 \mathrm{~m} / \mathrm{s}$ & $\begin{array}{c}\text { Not } \\
\text { Measurable }\end{array}$ & $\begin{array}{c}45.6 \mathrm{~cm}^{2} \\
(22.5 \mathrm{~cm} \times 2 \mathrm{~cm})\end{array}$ \\
\hline $\begin{array}{l}\text { OTT Parsivel }^{\circledR} \\
\text { disdrometer } \\
\text { (OTT Hydromet, } \\
\text { Loveland, } \\
\text { Colorado, USA) }\end{array}$ & $\begin{array}{l}\text { Krajewski et al. (2006) } \\
\text { [112]; Thurai et al. } \\
\text { (2009) [113]; } \\
\text { Friedrich et al. } \\
\text { (2013) [114] }\end{array}$ & $<1200 \mathrm{~mm} / \mathrm{h}$ & $0.2-5 \mathrm{~mm}$ & $0.2-20 \mathrm{~m} / \mathrm{s}$ & $<30 \mathrm{KJ}$ & $\begin{array}{c}54 \mathrm{~cm}^{2} \\
(18 \mathrm{~cm} \times 3 \mathrm{~cm})\end{array}$ \\
\hline $\begin{array}{c}\text { Particulate } \\
\text { Measurement } \\
\text { System (PMS) 2DG } \\
\text { spectrometer } \\
\text { (Particle Measuring } \\
\text { Systems, Airport } \\
\text { Blvd Boulder, } \\
\text { Colorado, USA) }\end{array}$ & Hawke (2003) [115] & $\begin{array}{c}\text { Not } \\
\text { Measurable }\end{array}$ & $\begin{array}{l}0.15-9.6 \mathrm{~mm} \\
\quad \text { (in } 64 \\
0.15 \mathrm{~mm} \text { size } \\
\text { categories) }\end{array}$ & $<25 \mathrm{~m} / \mathrm{s}$ & Measurable & $100 \mathrm{~mm}^{2}$ \\
\hline $\begin{array}{l}\text { Paired-pulse optical } \\
\text { disdrometer } \\
\text { (P-POD) }\end{array}$ & $\begin{array}{l}\text { Grossklaus et al. } \\
\text { (1998) [116] }\end{array}$ & $\begin{array}{c}\text { Not } \\
\text { Measurable }\end{array}$ & $0.35-6.4 \mathrm{~mm}$ & Measurable & $\begin{array}{c}\text { Not } \\
\text { Measurable }\end{array}$ & $\begin{array}{l}\text { Cylindrical } \\
\text { volume with } \\
120 \mathrm{~mm} \text { length } \\
\text { and } 22 \mathrm{~mm} \\
\text { diameter }\end{array}$ \\
\hline $\begin{array}{l}\text { Particle Measuring } \\
\text { System GBPP-100S }\end{array}$ & $\begin{array}{c}\text { Solomon et al. (1991) } \\
\text { [117] }\end{array}$ & Measurable & $\begin{array}{l}0.2-13 \mathrm{~mm} \text { in } \\
0.2 \mathrm{~mm} \\
\text { increments }\end{array}$ & Measurable & $\begin{array}{c}\text { Not } \\
\text { Measurable }\end{array}$ & $13 \times 500 \mathrm{~mm}^{2}$ \\
\hline $\begin{array}{l}\text { Paired pulse optical } \\
\text { disdrometer } \\
\text { (P-POD) }\end{array}$ & $\begin{array}{l}\text { Illingworth and } \\
\text { Stevens (1987) [118] }\end{array}$ & $\begin{array}{c}\text { Not } \\
\text { Measurable }\end{array}$ & $\begin{array}{c}0.72-3.62 \mathrm{~mm} \\
\text { in } 0.21 \mathrm{~mm} \\
\text { steps, } \\
<0.72 \text { and } \\
>3.62 \mathrm{~mm} \text { also } \\
\text { detectable }\end{array}$ & Measurable & $\begin{array}{c}\text { Not } \\
\text { Measurable }\end{array}$ & Measurable \\
\hline $\begin{array}{l}\text { VIDIAZ spectro } \\
\text { Pluvio meter }\end{array}$ & $\begin{array}{l}\text { Donnadieu } \\
\text { (1980) [119] }\end{array}$ & $\begin{array}{c}\text { Not } \\
\text { Measurable }\end{array}$ & $>0.6 \mathrm{~mm}$ & Measurable & $\begin{array}{c}\text { Not } \\
\text { Measurable }\end{array}$ & $80 \mathrm{~cm}^{2}$ \\
\hline $\begin{array}{c}\text { Optical spectro } \\
\text { pluviometer (OSP) }\end{array}$ & $\begin{array}{c}\text { Picca \&Trouilhet } \\
\text { (1964) [120], } \\
\text { Donnadieu et al. } \\
\text { (1969) [121], Klaus } \\
\text { (1977) [122], } \\
\text { Hauser et al. } \\
\text { (1984) [123], Salles \& } \\
\text { Poesen (1999) [124]; } \\
\text { Salles et al. } \\
\text { (1999) [125] }\end{array}$ & $\begin{array}{c}<35 \mathrm{~mm} / \mathrm{h} \\
\text { underestimates } \\
\text { intensity } \\
\text { by } 12 \% . \\
>35 \mathrm{~mm} / \mathrm{h}, \\
\text { underestimates } \\
\text { intensity } \\
\text { by } 38 \% .\end{array}$ & $\begin{array}{l}0.3-4.7 \mathrm{~mm} \\
( \pm 6 \%) \text { (Larger } \\
\text { drops are } \\
\text { detected but } \\
\text { without } \\
\text { quantification } \\
\text { of their } \\
\text { diameter) }\end{array}$ & $0.2-10 \mathrm{~m} / \mathrm{s}$ & $\begin{array}{c}\text { Not } \\
\text { Measurable }\end{array}$ & Not reported \\
\hline
\end{tabular}

\subsection{Optical Disdrometers}

Optical technologies (optical imaging or optical scattering) are non-intrusive rain drop measurement techniques. These methods do not influence drop behaviour during measurement, and have successfully resolved drop break up, and drop splatter problems experienced by other measurement methods [126,127]. 


\subsubsection{Optical Imaging}

Recent imaging techniques developed have involved two motion cameras (2DVD) to show raindrop microstructure, including front and side drop contours, fall velocity, drop cant and horizontal velocity. General rainfall parameters such as rain intensity and drop size distributions have also been accurately measured [128]. Two motion cameras record images of drops which have been used to accurately measure drop velocity, diameter, and shape (including oblateness, Figure 6). Measurement errors arising from drop drift caused by the tall unit design have led to design modifications, including the development of an indoor model [129], and one specifically designed for outdoor use [127].
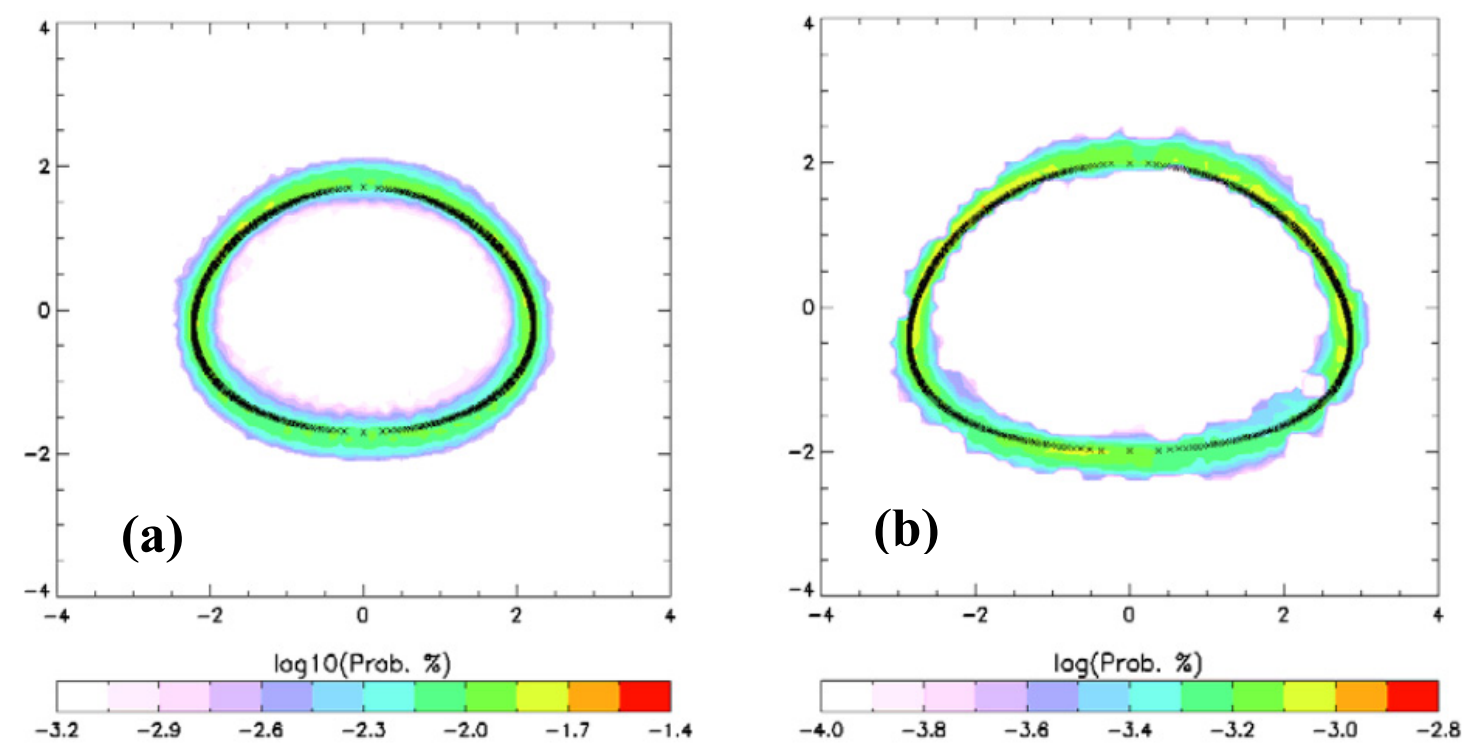

Figure 6. Drop shapes in terms of probability of (a) $4 \mathrm{~mm}$ and (b) $5 \mathrm{~mm}$ obtained from 2DVD [113].

Liu et al. [130] developed a video system capable of accurate drop shape and velocity measurement (Figure 7). The set up consists of optical and processing units, and a unique imaging unit comprised of a planar array charge-coupled device (CCD) sensor. The shape, size, and velocity of drops can be accurately measured by a single CCD sensor.
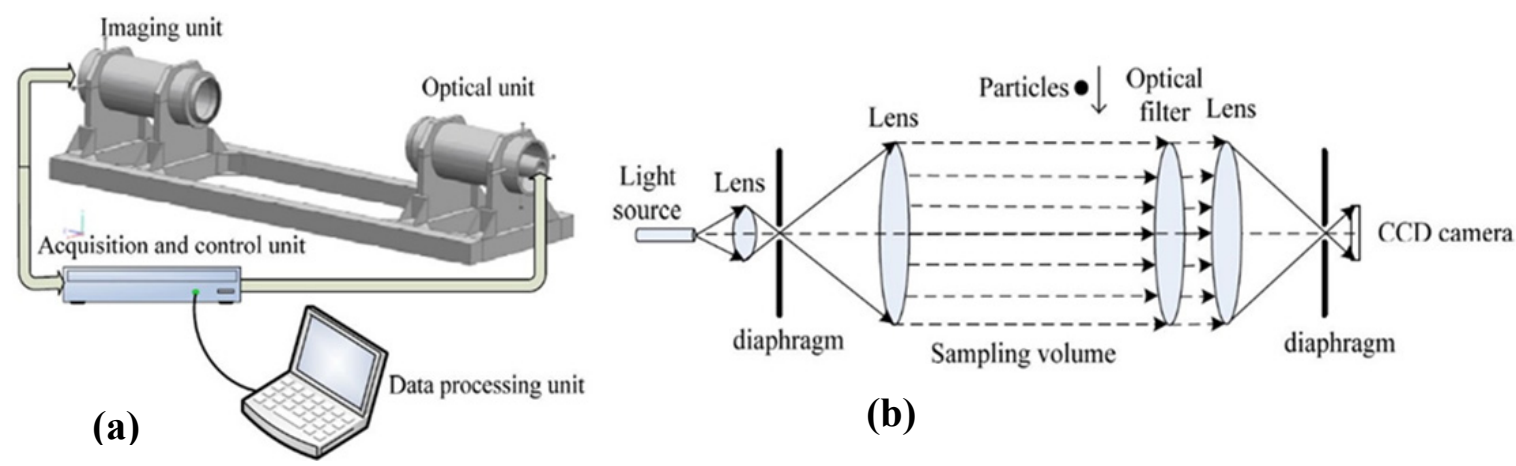

(b)

Figure 7. (a) Video setup; (b) Schematic of imaging process [129]. 


\subsubsection{Optical Scattering}

Optical scattering techniques involve the generation of a horizontal light beam which travels to a receiver where electrical measurements are taken. Drops that pass through the light beam cause the light to scatter. The attenuation of the light caused by each drop is converted to an electrical pulse by the receiver which is then successfully converted to accurate drop velocity measurement [108] (Figure 8).

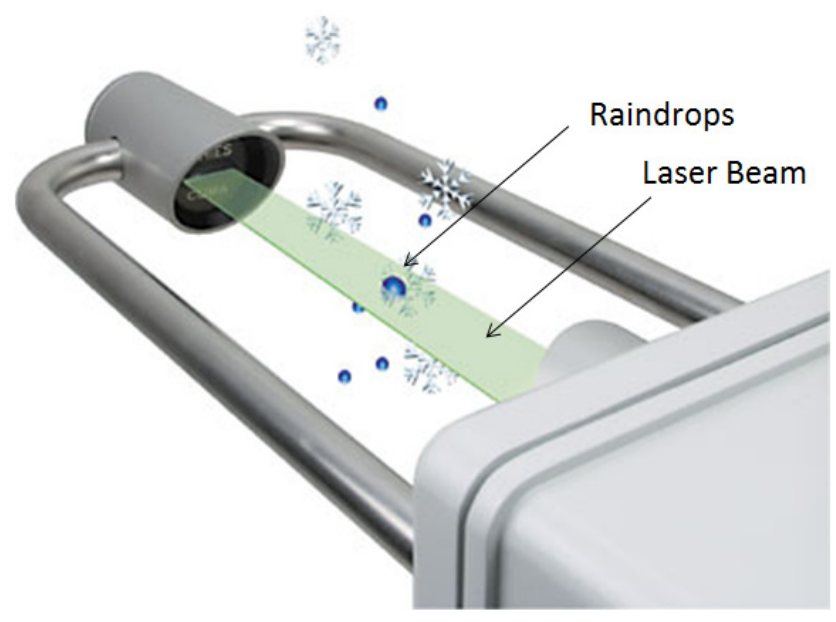

Figure 8. Schematic of optical disdrometer [108].

Since the mid-20th century, optical disdrometers have been used to successfully count and size individual rain drops [114,119-123,131-134] (Table 4). Performance evaluations have suggested that optical disdrometers may be limited to measuring larger drop sizes and that the rainfall intensity measurements were inaccurate $[9,124]$. Although optical disdrometers have also been found to be sensitive to wind effects [116], a modified version [118] included a paired pulse and was successfully used in windy conditions (wind speeds up to $20 \mathrm{~m} / \mathrm{s}$ ). Several models are also capable of successfully differentiating between solids and liquids, enabling use in the snow $[135,136]$. 
Table 4. Summary of the Characteristics of Rain Droplet Measurement Techniques.

\begin{tabular}{|c|c|c|c|c|c|c|c|c|c|}
\hline & $\begin{array}{l}\text { Stain } \\
\text { Method }\end{array}$ & FPM & $\begin{array}{c}\text { Oil } \\
\text { Immersion } \\
\text { Technique } \\
\end{array}$ & $\begin{array}{l}\text { Photography } \\
\text { Technique }\end{array}$ & $\begin{array}{c}\text { JWD RD } 80 \& \\
\text { RD } 69 \\
\text { Disdrometer }\end{array}$ & $\begin{array}{l}\text { VR-WXT520 } \\
\text { Disdrometer }\end{array}$ & $\begin{array}{c}2 \text { Dimensional } \\
\text { Video } \\
\text { Disdrometer }\end{array}$ & $\begin{array}{l}\text { OTT Parsivel } \\
\text { Disdrometer }\end{array}$ & $\begin{array}{l}\text { Laser Optical } \\
\text { Disdrometer }\end{array}$ \\
\hline Principle & Manual & Manual & Manual & $\begin{array}{c}\text { Optical } \\
\text { Technology }\end{array}$ & $\begin{array}{c}\text { Impact } \\
\text { Displacement } \\
\text { Technology }\end{array}$ & $\begin{array}{c}\text { Impact } \\
\text { Acoustic } \\
\text { Technology }\end{array}$ & $\begin{array}{c}\text { Optical } \\
\text { Technology }\end{array}$ & $\begin{array}{l}\text { Optical Laser } \\
\text { Technology }\end{array}$ & $\begin{array}{c}\text { Optical Laser } \\
\text { Technology }\end{array}$ \\
\hline $\begin{array}{l}\text { Measurability of } \\
\text { larger drops }\end{array}$ & $2.0 \mathrm{~mm}$ & $5 \mathrm{~mm}$ & $2.1 \mathrm{~mm}$ & Not reported & $5.0-5.5 \mathrm{~mm}$ & $5.0 \mathrm{~mm}$ & $\begin{array}{l}\text { Yes Range not } \\
\text { reported }\end{array}$ & $5.0-5.5 \mathrm{~mm}$ & $8.5 \mathrm{~mm}$ \\
\hline $\begin{array}{l}\text { Measurability of } \\
\text { smaller drops }\end{array}$ & $0.3 \mathrm{~mm}$ & $0.75 \mathrm{~mm}$ & Not reported & Not reported & $1.0 \mathrm{~mm}$ & $0.8 \mathrm{~mm}$ & $\begin{array}{l}\text { Yes Range not } \\
\text { reported }\end{array}$ & $0.2 \mathrm{~mm}$ & $0.125 \mathrm{~mm}$ \\
\hline $\begin{array}{c}\text { Measurability of } \\
\text { counting the } \\
\text { number of droplets }\end{array}$ & Yes & Yes & Yes & No & No & No & Yes & Yes & Yes \\
\hline $\begin{array}{l}\text { Measurability of the } \\
\text { rain fall velocity }\end{array}$ & No & No & No & Yes & No & No & Yes & $20 \mathrm{~m} / \mathrm{s}$ & $11 \mathrm{~m} / \mathrm{s}$ \\
\hline $\begin{array}{l}\text { Measurability of the } \\
\text { rain kinetic energy }\end{array}$ & No & No & No & No & No & No & No & Yes up to $30 \mathrm{~kJ}$ & No \\
\hline $\begin{array}{l}\text { Measurability of the } \\
\text { rain intensity }\end{array}$ & No & No & No & No & No & No & Yes & Yes & Yes \\
\hline $\begin{array}{l}\text { Ability to account } \\
\text { the oblateness }\end{array}$ & No & No & No & No & No & No & Yes & No & No \\
\hline $\begin{array}{l}\text { Ability to sampling } \\
\text { continuously for } \\
\text { longer durations }\end{array}$ & No & No & No & No & Yes & Yes & Yes & Yes & Yes \\
\hline $\begin{array}{l}\text { Resilience to the } \\
\text { wind effects }\end{array}$ & No & No & No & No & No & No & No & No & No \\
\hline${ }^{*}$ Resolution & & & & & 127 classes & 8 classes & & $\begin{array}{c}1014 \\
(32 \text { size } \times 32 \text { velocity })\end{array}$ & $\begin{array}{l}430 \text { classes } \\
(23 \times 20)\end{array}$ \\
\hline Temporal resolution & & & & & $1 \mathrm{~min}$ & $1 \mathrm{~min}$ & & $10 \mathrm{~s}$ to $60 \mathrm{~min}$ & $1 \mathrm{~min}$ \\
\hline
\end{tabular}




\section{Characteristics of a Robust Rainfall Droplet Measurement Technique}

For a realistic prediction and monitoring of droplet characteristics, a robust rainfall measurement instrument must be able to:

- Measure both larger (up to $10 \mathrm{~mm}$ ) and smaller (down to $0.3 \mathrm{~mm}$ ) drop sizes precisely;

- Count the drop sizes accurately;

- Measure the fall velocity precisely;

- Measure the rainfall intensities across all expected ranges;

- Sample continuously; and

- Tolerate wind effects while retaining drop measurement precision.

The possibility of achieving these target characteristics using the full range of available techniques is discussed below.

\subsection{Precise Measurement of Larger Rain Drops}

Because larger rain drops $(>6 \mathrm{~mm})$ are correlated with larger pollution wash off from urban areas [110], their accurate measurement is essential to stormwater quality studies that utilise rainfall simulation. Accurate manual rain drop measurement is limited to a maximum of approximately $2 \mathrm{~mm}$ in diameter due to splashing effects distorting results $[7,17,137]$. Large size drops are often overestimated due to the drop size growth over time on absorbent paper during use of the stain method [138]. The flour pellet method is limited to measurement of drops larger than about $0.5 \mathrm{~mm}$ due to sieve size limitations [5]. The measurement of larger drops using the oil immersion method is limited to $2.1 \mathrm{~mm}$ diameter due to drop splatter and amalgamation of drops [7,53,59].

Automated measurement techniques such as the impact disdrometers are also limited to the measurement of drops less than $5.5 \mathrm{~mm}$ because of a reliance on calculations using the relationship between velocity-diameter which plateaus beyond this diameter range using current formulae $[53,113,139]$. Although the two dimensional video and laser particle methods claim to have the capacity to precisely measure drop sizes as large as $10 \mathrm{~mm}$, peer reviewed studies to confirm this are yet to be published.

\subsection{Precise Measurement of Smaller Rain Drops}

The accurate measurement of small raindrops is challenging using both manual and automated techniques. Manual raindrop measurement techniques are restricted to precise measurement of drops of greater than $0.3 \mathrm{~mm}$ diameter $[15,33,44,59,61,66,140]$. Automated measurement techniques are also restricted to measurement of drops greater than $1 \mathrm{~mm}$ in size [141].

Several studies reported difficulties in relation to impact disdrometers and the measurement of smaller raindrop diameters $[85,134,142,143]$. Intense rainfall causes splashing and vibrations is also reported to distort the measurement of smaller drop sizes [142,144,145]. Measurement accuracy difficulties caused by laser technology recovery time (dead time error), and noise distortion that affect the measurement of smaller drop sizes are known to restrict precise measurement to $1 \mathrm{~mm}$ effects [145-148].

Acoustic disdrometers have limitations arising from the duration of the decaying waveform which when measured leads to distorted results [94,149]. Optical disdrometers claim to measure smaller drops with more precision, however, the reliability of these measurements remains unreported.

\subsection{Accurate Measurement of the Number of Rain drops}

Accurate measurement of the number of drops is critical for the generation of a drop size distribution for any given rainfall event. This is the most widely used characteristic used to describe rainfall $[150,151]$. Manual measurement techniques have a good capacity to accurately count drop numbers over short durations. Automated disdrometers such as laser precipitation monitors have the 
capacity to accurately sample over the longer durations required by rainfall sampling studies. However, limitations on the measurement accuracy of drops below $0.2 \mathrm{~mm}$ remain due to drop splatter [152] and background noise [112]. Optical disdrometers claim to accurately count drop numbers, however, the reliability of these measurements has also not been verified or reported.

\subsection{Precise Measurement of Rain Drop Velocity}

Manual techniques are not capable of measuring drop velocity with an adequate level of precision [153]. Although limited to static measurements, and defined by frame capture rate per second, photographic techniques are capable of precise drop velocity measurement. Video technique measurement (2DVD), laser precipitation monitors, and optical spectral pluviometers can also provide precise, continuous drop velocity measurements.

\subsection{Ability to Measure a Wide Range of Rainfall Intensities}

Because of the particular features of each technique, none of the manual rain drop measurement techniques, nor the impact disdrometer methods are capable of measuring rainfall intensity reliably. Although overestimation of higher rainfall intensities ( $>20 \mathrm{~mm} / \mathrm{h}$ ) is common, optical laser and video (2DVD) measurement of rainfall intensity are generally accepted as more accurate [154]. Due to the limitations regarding accurate measurement of high rainfall intensities, it is recommended that optical laser techniques are used in combination with a conventional pluviometer to enable measurements to be verified and to ensure accurate rain intensity measurement.

\subsection{Precise Measurement of Rain Drop Shape (Oblateness)}

Initially spherical due to surface tension forces, with increasing size, fall velocity and drag forces, rain drops tend to flatten out at the base, and sometimes develop a concave shape (Figure 6). The degree of oblateness may affect the kinetic energy of the drop, and thus the potential wash-off process caused by drop impact. Efforts to precisely measure the oblateness of larger drops have been limited, and it has been suggested that as yet, it may not be accurately described [155].

\subsection{Capacity to Accurately Sample Rainfall over a Long Duration}

Restricted sampling durations are synonymous with manual raindrop measurement techniques [156,157]. Automated disdrometers (laser, optical, acoustic, and impact) are known to measure rain drops in real time with virtually no time duration limitation. However, as discussed above, the accuracy of these devices can be limited.

\subsection{Capacity to Perform Precise Rain Drop Measurement during Adverse wind Conditions}

Because sampling time is usually quite brief, all of the manual measurement techniques are known to be accurate (within their individual output limitations) during windy conditions. Air movement and wind noise around automated samplers (disdrometers, video, and acoustic) are known to influence rain drop trajectory and sound filtering, which have been shown to lead to inaccuracies in drop size measurements in previous studies [86,152,158]. Wind effects were reduced to an acceptable level in one previous study by tilting an acoustic disdrometer parallel to wind direction [114]. However, this does not offer a reliable or permanent solution.

\section{Summary and Conclusion}

Every rainfall measurement technique has strengths and weaknesses and these generally result in some limitation in the accuracy of rain drop characteristic measurements. The precise requirements of any proposed study will determine the most appropriate method or combination of methods that should be used to produce the most suitable and accurate raindrop measurements. This is particularly the case for stormwater management purposes, particularly in relation to understanding how different 
raindrop characteristics affect pollution wash off processes and how this influences stormwater runoff quality from urban areas.

The main findings of this review have been:

- The use of manual rain drop measurement techniques have been successfully used in studies involving drop size measurements. However, these methods are generally not suitable for the measurement of smaller and larger drop sizes outside the normal range $(0.3-6 \mathrm{~mm})$, they are not capable of precise drop counts, they are not suitable for continuous rainfall monitoring studies, and they are less effective during intense and windy storm conditions. In addition, manual rain drop measurement techniques cannot be used to measure or report drop velocity.

- Automated (impact and optical) disdrometers are generally able to sample continuously over long durations. However, inaccuracies in drop size and velocity measurements are likely during heavy rain. It is recommended that optical disdrometers should be used in combination with a conventional rain gauge to enable validation of results and ensure precise rain intensity measurement.

The common limitations of all the rain drop measurement techniques includes their inability to precisely measure both the smaller, and the larger drop sizes outside the normal size range, their inaccuracy during high intensity rainfall events, and their reduced measurement precision during windy conditions. With improvements in technology occurring on a nearly daily basis, it is anticipated that the accuracy and precision of automated rainfall measurement techniques will significantly improve in the near future. This will enable more precise measurements to be undertaken and result in a much better understanding of real rainfall characteristics.

Author Contributions: All three authors contributed equally to this manuscript.

Conflicts of Interest: The authors declare no conflict of interest.

\section{References}

1. Schönhuber, M.; Urban, H.; Baptista, J.P.; Randeu, W.L.; Riedler, W. Measurements of precipitation characteristics by a new distrometer. In Proceedings of Atmospheric Physics and Dynamics in the Analysis and Prognosis of Precipitation Fields, Rome, Italy, 15-16 November 1994; pp. 15-18.

2. Testud, J.; Oury, S.; Black, R.A.; Amayenc, P.; Dou, X. The Concept of “Normalized” Distribution to Describe Raindrop Spectra: A Tool for Cloud Physics and Cloud Remote Sensing. J. Appl. Meteorol. 2001, 40, 1118-1140. [CrossRef]

3. Krajewski, W.F.; Ciach, G.J.; Habib, E. An analysis of small-scale rainfall variability in different climatic regimes. Hydrol. Sci. J. 2003, 48, 151-162. [CrossRef]

4. Herngren, L.F. Build-up and Wash-off Process Kinetics of PAHs and Heavy Metals on Paved Surfaces Using Simulated Rainfall. Ph.D. Thesis, Queensland University of Technology, Brisbane, Australia, 2005.

5. Hudson, N.W. Instrument for Studies of the Erosive Power of Rainfall, Erosion and Sediment Transport Measurement. In Proceedings of the Florence Symposium, 22-26 June 1981; International Association of Hydrological Sciences (IAHS): Ottawa, ON, Canada; pp. 383-393.

6. Wiesner, J. Beitrage zur Kenntnis des troischen regens (About Contributions to the knowledge of the tropical rain). Atmos. Electr. 1895, 104, 1397-1434.

7. Pearson, J.E.; Martin, G.E. An evaluation of raindrop sizing and counting techniques. Sci. Rep. 1957, 1, 1-17.

8. Blanchard, D.C. Raindrop Size Distribution and Associated Phenomena in Hawaiian Rains; No. R52; Woods Hole Oceanographic Institution: Woods Hole, MA, USA, 1952.

9. Lowe, E.J. Rain drops. Q. J. R. Meteorol. Soc. 1892, 18, 242-245. [CrossRef]

10. Marshall, J.S.; Palmer, W.M.K. The distribution of raindrops with size. J. Meteorol. 1948, 5, 165-166. [CrossRef]

11. Marshall, J.S.; Langille, R.C.; Palmer, W.M.K. Measurement of rainfall by radar. J. Meteorol. 1947, 4, $186-192$. [CrossRef]

12. Anderson, L.J. Drop-size distribution measurements in orographic rain. Bull. Am. Met. Soc. 1948, 29, 362-366.

13. Abudi, I.; Carmi, G.; Berliner, P. Rainfall simulator for field runoff studies. J. Hydrol. 2012, 454, 76-81. [CrossRef] 
14. Best, A.C. The size distribution of raindrops. Q. J. R. Meteorol. Soc. 1950, 76, 16-36. [CrossRef]

15. Hall, M.J. Use of the stain method in determining the drop-size distributions of coarse liquid sprays. Am. Soc. Agric. Eng. Trans. 1970, 13, 33-37. [CrossRef]

16. Shiotsuki, Y. On the flat size distribution of drops from convective rainclouds. J. Meteorol. Soc. Jpn. 1974, 52, 42-60.

17. Shiotsuki, Y. An estimation of drop-size distribution in the severe rainfall. J. Meteorol. Soc. Jpn. 1976, 54, 259-263.

18. Brandt, C.J. Transformation of the Kinetic Energy of Rainfall with Variable Tree Canopy. Ph.D. Thesis, University of London, London, UK, 1986.

19. Brandt, C.J. The transformation of rainfall energy by a tropical rain forest canopy in relation to soil erosion. J. Biogeogr. 1988, 15, 41-48. [CrossRef]

20. Brandt, C.J. Simulation of the size distribution and erosivity of raindrops and throughfall drops. Earth Surf. Process. Landf. 1990, 15, 687-698. [CrossRef]

21. Cerdà, A. Rainfall drop size distribution in the Western Mediterranean basin, València, Spain. Catena 1997, 30, 169-182. [CrossRef]

22. Lu, J.Y.; Su, C.C.; Lu, T.F.; Maa, M.M. Number and volume raindrop size distributions in Taiwan. Hydrol. Process. 2008, 22, 2148-2158. [CrossRef]

23. Bowen, E.G.; Davidson, K.A. A raindrop spectrograph. Q. J. R. Meteorol. Soc. 1951, 77, 445-449. [CrossRef]

24. Blanchard, D.C. A simple recording technique for determining raindrop size and time of occurrence of rain showers. EOS Trans. Am. Geophys. Union 1953, 34, 534-538. [CrossRef]

25. Imai, I.; Fujiwara, M.; Ichimura, I.; Yoshihara, Z. On the radar reflectivity and the drop-size distribution of rain. J. Meteorol. Tokyo 1955, 7, 422-433.

26. Spencer, A.T.; Blanchard, D.C. An Automatic Raindrop Sampler; No. TR-11; Woods Hole Oceanographic Institution: Woods Hole, MA, USA, 1956.

27. Gillespie, T. The spreading of low vapor pressure liquids in paper. J. Colloid Sci. 1958, 13, 32-50. [CrossRef]

28. Becker, A. Zur messung der Tropfengroessen bei Regenfaellen nach der Absorption methode. (About measurement of drop sizes in rainfall according to the filter paper method). Meteorol. Z. 1907, 24, 247-261.

29. Neuberger, H. Notes on measurement of rain-drop sizes. Bull. Am. Meteorol. Soc. 1942, 23, $274-276$.

30. Quinn, N.W.T. Properties of Transformed Simulated Rainfall under a Corn Canopy at Different Growth Stages and Row Widths. Masters Thesis, Iowa State University, Ames, IA, USA, 1981.

31. Bentley, W.A. Studies of raindrops and raindrop phenomena. Mon. Weather Rev. 1904, 32, 450-456.

32. Kohl, R.A. Drop size distributions from medium-sized agricultural sprinklers. Am. Soc. Agr. Eng. Trans. 1974, 17, 690-693. [CrossRef]

33. Hudson, N.W. Raindrop size distribution in high intensity storms. Rhodesian J. Agric. Res. 1963, 1, 6-11.

34. Regmi, T.P.; Thompson, A.L. Rainfall simulator for laboratory studies. Appl. Eng. Agric. 2000, 16, 641-652. [CrossRef]

35. Ogunye, F.O.; Boussabaine, H. Development of a rainfall test rig as an aid in soil block weathering assessment. Constr. Build. Mater. 2002, 16, 173-180. [CrossRef]

36. Júnior, S.S.; Siqueira, E.Q. Development and Calibration of a Rainfall Simulator for Urban Hydrology Research. In Proceedings of 12th International Conference on Urban Drainage, Porto Alegre, Brazil, 11-16 September 2011; pp. 226-231.

37. Lascelles, B.; Favis-Mortlock, D.T.; Parsons, A.J.; Guerra, A.J. Spatial and temporal variation in two rainfall simulators: Implications for spatially explicit rainfall simulation experiments. Earth Surf. Process. Landf. 2000, 25, 709-721. [CrossRef]

38. Miguntanna, N.P. Nutrients build-up and wash-off processes in urban land uses. Ph.D. Thesis, Queensland University of Technology, Brisbane, Australia, 2009.

39. Pérez-Latorre, F.J.; de Castro, L.; Delgado, A. A comparison of two variable intensity rainfall simulators for runoff studies. Soil Tillage Res. 2010, 107, 11-16. [CrossRef]

40. Arnaez, J.; Lasanta, T.; Ruiz-Flaño, P.; Ortigosa, L. Factors affecting runoff and erosion under simulated rainfall in Mediterranean vineyards. Soil Tillage Res. 2007, 93, 324-334. [CrossRef]

41. Simone, A.; Vignali, V.; Bragalli, C.; Maglionico, M. Surface run-off: A rainfall simulator for wash-off modelling and road safety auditing under different rainfall intensities. In Proceedings of the second International SIIV Congress, Firenze, Italy, 27-29 October 2004. 
42. Parsons, A.J.; Stone, P.M. Effects of intra-storm variations in rainfall intensity on interrill runoff and erosion. Catena 2006, 67, 68-78. [CrossRef]

43. Clarke, M.A.; Walsh, R.P. A portable rainfall simulator for field assessment of splash and slopewash in remote locations. Earth Surf. Process. Landf. 2007, 32, 2052-2069. [CrossRef]

44. Egodawatta, P.K. Translation of Small-plot Scale Pollutant Build-up and Wash-off Measurements to Urban Catchment Scale. Ph.D. Thesis, Queensland University of Technology, Brisbane, Australia, 2007.

45. Asante, E.A. Effect of Mulch Type, Mulch Rate and Slope on Soil Loss, Runoff and Infiltration Under Simulated Rainfall for Two Agricultural Soils in Ghana. Ph.D. Thesis, University of Science and Technology, Kumasi, Ghana, 2011.

46. Parsakhoo, A.; Lotfalian, M.; Kavian, A.; Hoseini, S.A.; Demir, M. Calibration of a portable single nozzle rainfall simulator for soil erodibility study in hyrcanian forests. Afr. J. Agric. Res. 2012, 7, 3957-3963.

47. Laws, J.O.; Parsons, D.A. The relation of raindrop size to intensity. Am. Geophysical Union Trans. 1943, 26, 452-460. [CrossRef]

48. Carter, C.E.; Greer, J.D.; Braud, H.J.; Floyd, J.M. Raindrop characteristics in South Central United States. Am. Soc. Agric. Eng. Trans. 1974, 17, 1033-1037. [CrossRef]

49. Navas, A.; Alberto, F.; Machín, J.; Galán, A. Design and operation of a rainfall simulator for field studies of runoff and soil erosion. Soil Technol. 1990, 3, 385-397. [CrossRef]

50. Fuchs, N.; Petrjanoff, I. Microscopic examination of fog, cloud and rain droplets. Nature 1937, 139, 111-112. [CrossRef]

51. May, K.R. The cascade impactor: An instrument for sampling coarse aerosols. J. Sci. Instrum. 1945, 22, 187-195. [CrossRef]

52. Lane, W.R. A Microburette for producing small liquid drops of known size. J.Sci. Instrum. 1947, $24,98-101$. [CrossRef]

53. Gunn, R.; Kinzer, G.D. The terminal velocity of fall for water droplets in stagnant air. J. Meteorol. 1949, 6, 243-248. [CrossRef]

54. Tate, R.W. Immersion sampling of spray droplets. AIChE J. 1961, 7, 574-577. [CrossRef]

55. Nawaby, A.S. A Method of Direct Measurement of Spray Droplets in an Oil Bath. J. Agric. Res. 1970, 15, 182-184. [CrossRef]

56. McCool, D.K.; Williams, J.D.; Morse, J.R. Raindrop characteristics in the Pacific Northwest. In Proceedings of American Society of Agricultural and Biological Engineers (ASABE) Annual International Meeting, Reno, NV, USA, 11-14 October 2009; Volume 97441, pp. 21-24.

57. Eigel, J.D.; Moore, I.D. A simplified technique for measuring raindrop size and distribution. Amer. Soc. Agr. Eng. Trans. 1983, 24, 1079-1083. [CrossRef]

58. Cruvinel, P.E.; Minatel, E.R.; Mucheroni, M.L.; Vieira, S.R.; Crestana, S. An Automatic Method Based on Image Processing for Measurements of Drop Size Distribution from Agricultural Sprinklers. In Proceedings of Simpósio Brasileiro de Computação Gráfica e Processamento de Imagens (SIBGRAPI), Caxambú- Minas Gerais, Brazil, 29 October-1 November 1996; pp. 39-46.

59. Courshee, R.J.; Byass, J.B. A Study of the Methods of Measuring Small Spray Drops; National Institute of Agricultural Engineering: Bedford, UK, 1953.

60. Hacker, P.T. An Oil-stream Photomicrographic Aeroscope for Obtaining Cloud Liquid-water Content and Droplet Size Distributions in Flight. National Advisory Committee for Aeronautics: Lewis Flight Propulsion Laboratory, Cleveland, OH, USA, 1956; Technical Note 3592. pp. 1-36. Available online: http:/ /digital.library.unt.edu/ark:/67531/metadc53544/m2/1/high_res_d/19810068735.pdf (accessed on 10 January 2016).

61. Cruvinel, P.E.; Vieira, S.R.; Crestana, S.; Minatel, E.R.; Mucheroni, M.L.; Neto, A.T. Image processing in automated measurements of raindrop size and distribution. Comput. Electron. Agric. 1999, 23, $205-217$. [CrossRef]

62. Golitzine, N. Method for Measuring the Size of Water Droplets in Clouds, Fogs, and Sprays; Note 6; National Aeronautical Establishment: Ottowa, ON, Canada, 1951; pp. 1-52.

63. Bigg, F.J.; Abel, G.C. Note on Sampling and Photographing Cloud Droplets in Flight; RAE TN-ME-156; Royal Aircraft Establishment: Farnborough, UK; September; 1953; pp. 46-57.

64. Brown, E.N.; Willett, J.H. A three-slide cloud droplet sampler. Bull. Am. Meteorol. Soc. 1955, 36, $123-127$. 
65. Blanquies, J.; Scharff, M.; Hallock, B. The Design and Construction of a Rainfall Simulator, International Erosion Control Association (IECA). In Proceedings of 34th Annual Conference and Expo, Las Vegas, NV, USA, 24-28 February 2003; p. 10.

66. Houghton, H.G.; Radford, W.H. On the Measurement of Drop Size and Liquid Water Content in Fogs and Clouds; Physical Oceanography and Meteorology: Cambridge, MA, USA, 1938; Volume 6, pp. 5-31.

67. Baumgardner, D.; Jonsson, H.; Dawson, W.; O'Connor, D.; Newton, R. The cloud, aerosol and precipitation spectrometer: A new instrument for cloud investigations. Atmos. Res. 2001, 59-60, 251-264. [CrossRef]

68. Mache, H. Ueber die Geschwindigkeit un Grosse der Regentrpfen. Meteorol. Z. 1904, 39, 278.

69. Laws, J.O. Measurements of the fall-velocity of water-drops and raindrops. Am. Geophys. Union Trans. 1941, 22, 709-721. [CrossRef]

70. Mason, B.J.; Ramanadham, R. A photoelectric raindrop spectrometer. Q. J. R. Meteorol. Soc. 1953, 79, 490-495. [CrossRef]

71. Mikirov, A.E. A photoelectric method of investigating the distribution of particle size precipitation. Izv. Akad. Nauk. SSSR 1957, 1, 104.

72. Salvador, R.; Bautista-Capetillo, C.; Burguete, J.; Zapata, N.; Serreta, A.; Playán, E. A photographic method for drop characterization in agricultural sprinklers. Irrig. Sci. 2009, 27, 307-317. [CrossRef]

73. De Jong, S. Low Cost Disdrometer. Masters Thesis, Delf University of Technology, Delft, The Netherlands, 2010.

74. Sadeghi, S.H.; Abdollahi, Z.; Darvishan, A.K. Experimental comparison of some techniques for estimating natural raindrop size distribution on the south coast of the Caspian Sea, Iran. Hydrol. Sci. J. 2013, 58, 1374-1382. [CrossRef]

75. Sudheer, K.P.; Panda, R.K. Digital image processing for determining drop sizes from irrigation spray nozzles. Agric. W. Manag. 2000, 45, 159-167. [CrossRef]

76. Kincaid, D.C.; Solomon, K.H.; Oliphant, J.C. Drop size distributions for irrigation sprinklers. Amer. Soc. Agr. Eng. Trans. 1996, 39, 839-845. [CrossRef]

77. Mueller, E.A. Radar cross sections from drop size spectra. Ph.D. Thesis, University of Illinois at Urbana-Champaign, Champaign, IL, USA, 1966.

78. Jones, D.M. The shape of raindrops. J. Meteorol. 1959, 16, 504-510. [CrossRef]

79. Jones, D.M.; Dean, L.A. A Raindrop Camera; Illinois State Water Survey: Champaign, IL, USA, 1953.

80. Jones, D.M. Rainfall Drop Size-distribution and Radar Reflectivity; Defense Technical Information Center, Signal Corps Engineering Laboratories: Fort Monmouth, NJ, USA, 1956.

81. Fujiwara, M. Raindrop-size distribution from individual storms. J. Atmos. Sci. 1965, 22, 585-591. [CrossRef]

82. Vaisala. Vaisala Weather Transmitter WXT510 with the Vaisala RAINCAP ${ }^{\circledR}$ Sensor. 2012, 1. Available online: www.vaisala.com (accessed on 15 June 2015).

83. Jayawardena, A.W.; Rezaur, R.B. Measuring drop size distribution and kinetic energy of rainfall using a force transducer. Hydrol. Process. 2000, 14, 37-49. [CrossRef]

84. Salmi, A.; Elomaa, L. Measurements of the Terminal Velocity and Shape of Falling Raindrops at Vaisala Rain Laboratory. In Proceedings of Eighth European Conference on Application of Meteorology (ECAM), San Lorenzo de El Escorial, Spain, 1-5 October 2007; pp. 55-61.

85. Kinnell, P.I.A. Some observations on the Joss-Waldvogel rainfall disdrometer. J. Appl. Meteorol. 1976, 15, 499-502. [CrossRef]

86. Winder, P.; Paulson, K.S. The measurement of rain kinetic energy and rain intensity using an acoustic disdrometer. Meas. Sci. Technol. 2012, 23, 015801. [CrossRef]

87. Schindelhauer, F. Versuch einer Registrierung der Tropfenzahl bei Regenfallen (An Attempt to Record the Number of Drops in Rain); Scientific Report No. 1; Meteorologische Zeitschrift: Brunswick, Germany, 1925; pp. 25-27.

88. Perez, A.A. The Analysis and Preliminary Synthesis of a Drop Size Distribution Measuring System; Massachusetts Institute of Technology: Cambridge, MA, USA, 1949.

89. Cooper, B.F. A Balloon-borne Instrument for Telemetering Raindrop-size Distribution and Rainwater Content of Cloud. Aust. J. Appl. Sci. 1951, 2, 43-55.

90. Maulard, J. Measure du Nombre de Gouttes de Pluie (Measurement of the number of drops of rain). J. Sci. Meteorol. 1951, 3, 69-73.

91. Katz, I. A momentum disdrometer for measuring raindrop size from aircraft. Bull. Am. Meteorol. Soc. 1952, 33, 365-368. 
92. Smulowicz, B. Analysis of the Impactometer: An Instrument for Measuring the Distribution of Raindrop Sizes Encountered in Flight. Ph.D. Thesis, Massachusetts Institute of Technology, Cambridge, MA, USA, 1952.

93. Adderley, E.E. The growth of raindrops in cloud. Q. J. R. Meteorol. Soc. 1953, 79, 380-388. [CrossRef]

94. Kinnell, P.I.A. The acoustic measurement of water-drop impacts. J. Appl. Meteorol. 1972, 11, 691-694. [CrossRef]

95. Kimble, P.D. Measuring the Momentum of Throughfall Drops and Raindrops. Ph.D. Thesis, Western Kentucky University, Bowling Green, KY, USA, 1996.

96. Nystuen, J.A. Relative performance of automatic rain gauges under different rainfall conditions. J. Atmos. Ocean. Technol. 1999, 16, 1025-1043. [CrossRef]

97. Salmi, A.; Ikonen, J. New piezoelectric Vaisala RAINCAPÒ precipitation sensor. In Proceedings of 19th Conference of Hydrology. Meteorolgical Society, San Diego, CA, USA, 9-13 January 2005; pp. 2-6.

98. Bagree, R. Characterization and Design of a Readout Circuit for a Piezoelectric-based Acoustic Disdrometer. Ph.D. Thesis, Delft University of Technology, Delft, The Netherlands, 2012.

99. Neal, J.H.; Baver, L.D. Measuring the impact of raindrops. Agron. J. 1937, 29, 708-709. [CrossRef]

100. Webster, D.K. An Investigation into the Use of Microprocessors for the Measurement of Rainfall Intensity; National College of Agricultural Engineering: Silsoe, Bedfordshire, UK, 1980.

101. Bass, H.G. Introduction to Engineering Measurements; McGraw-Hill Education: Columbus, OH, USA, 1971.

102. Henry, Z.A.; Zoerb, G.C.; Birth, G.S. Instrumentation and Measurement for Environmental Sciences; SP-0375; American Society of Agricultural Engineers: St. Joseph, MI, USA, 1991; pp. 5-91.

103. Joss, J.; Waldvogel, A. Ein spektrograph für niederschlagstropfen mit automatischer auswertung. Pure Appl. Geophys. 1967, 68, 240-246. [CrossRef]

104. Kinnell, P.I.A. Some observations on Joss-Waldvogel rainfall disdrometer-reply. J. Appl. Meteorol. 1977, 16, 113-114. [CrossRef]

105. Joss, J.; Waldvogel, A. Some observations on Joss-Waldvogel rainfall disdrometer-Reply. J. Appl. Meteorol. 1977, 16, 112-113. [CrossRef]

106. Distromet Ltd. Distromet. 2011. Available online: www.distromet.com (accessed on 15 June 2015).

107. Bloemink, H.I.; Lanzinger, E. Precipitation type from the Thies disdrometer. In Instruments and Observing Methods Report 82 (TD1265), In Proceedings of World Meterological Organization Technical Conference on Instruments and Methods of Observation (TECO-2005), Bucharest, Romania, 4-7 May 2005.

108. Clima, T. Laser Precipitation Monitor Instruction for Use: 5.4110.X0.X00; Software Version 1.04; Adolf Thies GmbH \& Co. KG: Göttingen, Germany, 2007.

109. Upton, G.; Brawn, D. An investigation of factors affecting the accuracy of Thies disdrometers. In Proceedings of World Meterological Organization Technical Conference on Instruments and Methods of Observation (TECO-2008), St. Petersburg, Russian Federation, 27-29 November 2008; pp. 27-29.

110. Anderson, D. Preliminary evaluation of OTT and Thies Clima present weather sensors. Program operations and standards Instrument Test Report 691. Bureau of Meteorology, Australian Government: Melbourne, Australia, 2009.

111. De Moraes Frasson, R.P.; da Cunha, L.K.; Krajewski, W.F. Assessment of the Thies optical disdrometer performance. Atmos. Res. 2011, 101, 237-255. [CrossRef]

112. Krajewski, W.F.; Kruger, A.; Caracciolo, C.; Golé, P.; Barthes, L.; Creutin, J.D.; Vinson, J.P. DEVEX-disdrometer evaluation experiment: Basic results and implications for hydrologic studies. Adv. W. Res. 2006, 29, 311-325. [CrossRef]

113. Thurai, M.; Bringi, V.N.; Petersen, W.A. Rain microstructure retrievals using 2-D video disdrometer and C-band polarimetric radar. Adv. Geosci. 2009, 20, 13-18. [CrossRef]

114. Friedrich, K.; Higgins, S.; Masters, F.J.; Lopez, C.R. Articulating and stationary PARSIVEL disdrometer measurements in conditions with strong winds and heavy rainfall. J. Atmos. Ocean. Technol. 2013, 30, 2063-2080. [CrossRef]

115. Hawke, R.M. Using a spectrometer to assess simulated rainfall: Research in action. S. Afr. J. Science 2003, $99,311$.

116. Grossklaus, M.; Uhlig, K.; Hasse, L. An optical disdrometer for use in high wind speeds. J. Atmos. Ocean. Technol. 1998, 15, 1051-1059. [CrossRef] 
117. Solomon, K.H.; Zoldoske, D.E.; Oliphant, J.C. Laser Optical measurement of Sprinkler Drop Sizes. In Proceedings of Automated Agriculture for the 21st Century, St. Joseph, MI, USA, 16-17 December 1991; pp. 87-96.

118. Illingworth, A.J.; Stevens, C.J. An optical disdrometer for the measurement of raindrop size spectra in windy conditions. J. Atmos. Ocean. Technol. 1987, 4, 411-421. [CrossRef]

119. Donnadieu, G. Comparison of results obtained with the VIDIAZ spectropluviometer and the Joss-Waldvogel rainfall disdrometer in a "rain of a thundery type". J. Appl. Meteorol. 1980, 19, 593-597. [CrossRef]

120. Picca, B.; Trouilhet, G. Un pluviogranulometre photoelectrique (A photoelectric raindrop-size spectrometer). J. Atmos. Res. 1964, 7, 184-188.

121. Donnadieu, G.; Dubosclard, G.; Godard, S. Un pluviometre ohotoelctrique pour la determination simultanee des spectres dimensionnel at de vitesse de chute des gouttes de pluie. J. Res. Atmos. 1969, 4, 37-46.

122. Klaus, V. Study Spectropluviomètre Photoelectric Providing Real-time Integrated Parameters. Ph.D. Thesis, University of Paris, Paris, France, 1977.

123. Hauser, D.; Amayenc, P.; Nutten, B.; Waldteufel, P. A new optical instrument for simultaneous measurement of raindrop diameter and fall speed distributions. J. Atmos. Ocean. Technol. 1984, 1, 256-269. [CrossRef]

124. Salles, C.; Poesen, J. Performance of an optical spectro pluviometer in measuring basic rain erosivity characteristics. J. Hydrol. 1999, 218, 142-156. [CrossRef]

125. Salles, C.; Poesen, J.; Borselli, L. Measurement of Simulated Drop Size Distribution with an Optical Spectro Pluviometer: Sample Size Considerations. Earth Surf. Process. Landf. 1999, 24, 545-556. [CrossRef]

126. Lanzinger, E.; Theel, M.; Windolph, H. Rainfall amount and intensity measured by the Thies laser precipitation monitor. In Instruments and Observing Method Report No. 94, 1-97, Proceedings of TECO-2006-WMO Technical Conference on Meteorological and Environmental Instruments and Methods of Observation, 4-6 December 2006; World Meteorological Organization: Geneva, Switherland, 2006.

127. Schönhuber, M.; Lammer, G.; Randeu, W.L. The 2D-video-distrometer. In Precipitation: Advances in Measurement, Estimation and Prediction; Springer: Berlin, Germany, 2008; pp. 3-31.

128. Schönhuber, M.; Lammer, G.; Randeu, W.L. One decade of imaging precipitation measurement by 2D-video-distrometer. Adv. Geosci. 2007, 10, 85-90. [CrossRef]

129. Nešpor, V.; Krajewski, W.F.; Kruger, A. Wind-induced error of raindrop size distribution measurement using a two-dimensional video disdrometer. J. Atmos. Ocean. Technol. 2000, 17, 1483-1492. [CrossRef]

130. Liu, X.C.; Gao, T.C.; Liu, L. A video precipitation sensor for imaging and velocimetry of hydrometeors. Atmos. Meas. Tech. 2014, 7, 2037-2046. [CrossRef]

131. Gucker, F.T., Jr. Determination of concentration and size of particulate matter by light scattering and sonic techniques. In Proceedings of First National Air Pollution Symposium, 10-11 November 1949; Stanford Research Institute: Los Angeles, CA, USA; pp. 14-25.

132. Knollenberg, R.G. The optical array: An alternative to scattering or extinction for airborne particle size determination. J. Appl. Meteorol. 1970, 9, 86-103. [CrossRef]

133. Knollenberg, R.G. Three new instruments for cloud physics measurements: The 2-D spectrometer, the forward scattering Spectrometer probe and the active scattering aerosol spectrometer. In Proceedings of International Conference on Cloud Physics, Boulder, Colo., American Meteorological Society, Boston, MA, USA, 26-30 July 1976; pp. 544-561.

134. Löffler-Mang, M.; Joss, J. An optical disdrometer for measuring size and velocity of hydrometeors. J. Atmos. Ocean. Technol. 2000, 17, 130-139. [CrossRef]

135. Battaglia, A.; Rustemeier, E.; Tokay, A.; Blahak, U.; Simmer, C. PARSIVEL snow observations: A critical assessment. J. Atmos. Ocean. Technol. 2010, 27, 333-344. [CrossRef]

136. Jaffrain, J.; Berne, A. Experimental quantification of the sampling uncertainty associated with measurements from PARSIVEL disdrometers. J. Hydrometeorol. 2011, 12, 352-370. [CrossRef]

137. Dingle, A.N.; Schulte, H.F., Jr. A research instrument for the study of raindrop-size spectra. J. Appl. Meteorol. 1962, 1, 48-59. [CrossRef]

138. Mason, B.J.; Andrews, J.B. Drop-size distributions from various types of rain. Q. J. R. Meteorol. Soc. 1960, 86, 346-353. [CrossRef]

139. Atlas, D.; Srivastava, R.C.; Sckhon, R.S. Doppler radar characteristics of precipitation at vertical incidence. Rev. Geophys. Sp. Phys. 1973, 11, 1-35. [CrossRef] 
140. Kobayaski, T. Measurement of Rain-drop Size by Means of Photographic Paper Treated with $\mathrm{COCl}_{2}$. J. Meteor. Soc. Jpn. 1995, 33, 217.

141. Roy, S.S.; Datta, R.K.; Bhatia, R.C.; Sharma, A.K. Drop size distributions of tropical rain over south India. Geofizika 2005, 22, 105-131.

142. List, R.A. Linear radar reflectivity-rainrate relationship for steady tropical rain. J. Atmos. Sci. 1988, 45, 3564-3572. [CrossRef]

143. Tokay, A.; Kruger, A.; Krajewski, W.F. Comparison of drop size distribution measurements by impact and optical disdrometers. J. Appl. Meteorol. 2001, 40, 2083-2097. [CrossRef]

144. Nystuen, J.A.; Proni, J.R.; Lauter, C.A.; Bufkin, J.; Rivero, U.; Boland, M.; Wilkerson, J.C. APL Disdrometer Evaluation; National Oceanic and Atmospheric Administration/Environmental Research Laboratories Technical Memorandum ERL AMOL-83 (PB95-181681): Miami, FL, USA, 1994.

145. Harikumar, R.; Sampath, S.; Kumar, V.S. An empirical model for the variation of rain drop size distribution with rain rate at a few locations in southern India. Adv. Sp. Res. 2009, 43, 837-844. [CrossRef]

146. Sheppard, B.E.; Joe, P.I. Comparison of raindrop size distribution measurements by a Joss-Waldvogel disdrometer, a PMS 2DG spectrometer, and a POSS Doppler radar. J. Atmos. Ocean. Technol. 1994, 11, 874-887. [CrossRef]

147. Tokay, A.; Bashor, P.G.; Habib, E.; Kasparis, T. Raindrop size distribution measurements in tropical cyclones. Mon. Weather Rev. 2008, 136, 1669-1685. [CrossRef]

148. Das, S.; Maitra, A.; Shukla, A.K. Rain attenuation modeling in the 10-100 GHz frequency using drop size distributions for different climatic zones in tropical India. Prog. Electromagn. Res. B 2010, 25, 211-224. [CrossRef]

149. De Wulf, F.D.; Gabriels, D.; Boodt, M.D. A device for analyzing the energy load of rainstorms. Assess. Eros. 1980, 165-167.

150. Campos, E.F.; Zawadzki, I.; Petitdidier, M.; Fernandez, W. Measurement of raindrop size distributions in tropical rain at Costa Rica. J. Hydrol. 2006, 328, 98-109. [CrossRef]

151. Konwar, M.; Sarma, D.K.; Das, J.; Sharma, S. Shape of the rain drop size distributions and classification of rain type at Gadanki. Indian J. Radio Sp. Phys. 2006, 35, 360-367.

152. Kruger, A.; Krajewski, W.F. Two-dimensional video disdrometer: A description. J. Atmos. Ocean. Technol. 2002, 19, 602-617. [CrossRef]

153. Montero-Martínez, G.; Kostinski, A.B.; Shaw, R.A.; García-García, F. Do all raindrops fall at terminal speed? Geophysical Res. Lett. 2009, 36, 1-4. [CrossRef]

154. do Khac, K.; Zanghi, F.; Tabary, P. Radar-disdrometer comparison. In Proceedings of Third European Conference on Radar Meteorology and Hydrology (ERAD), Visby, Sweden, 6-10 September 2004; pp. 272-277.

155. Beard, K.V.; Bringi, V.N.; Thurai, M. A new understanding of raindrop shape. Atmos. Res. 2010, 97, $396-415$. [CrossRef]

156. Erpul, G.; Gabriels, D.; Janssens, D. Assessing the drop size distribution of simulated rainfall in a wind tunnel. Soil Tillage Res. 1998, 45, 455-463. [CrossRef]

157. Salles, C.; Poesen, J.; Sempere-Torres, D. Kinetic energy of rain and its functional relationship with intensity. J. Hydrol. 2002, 257, 256-270. [CrossRef]

158. Habib, E.; Krajewski, W.F. An example of computational approach used for aerodynamic design of a rain disdrometer. J. Hydraul. Res. 2001, 39, 425-428. [CrossRef]

(C) 2016 by the authors; licensee MDPI, Basel, Switzerland. This article is an open access article distributed under the terms and conditions of the Creative Commons by Attribution (CC-BY) license (http://creativecommons.org/licenses/by/4.0/). 